\author{
고에너지 물질 시뮬란트의 분산도의 In-Line 모니터링 \\ 이상묵 · 홍인권 · 안영준* · 이재욱*, \\ 단국대학교 화학공학과, *서강대학교 화공생명공학과 \\ (2013년 10월 21일 접수, 2013년 12월 11일 수정, 2013년 12월 13일 채택)
}

\title{
In-Line Monitoring the Dispersion of Highly Energetic Material Simulant
}

\author{
Sangmook Lee, In-Kwon Hong, Youngjoon Ahn*, and Jae Wook Lee*,† \\ Division of Chemical Engineering, Dankook University, 126 Jukjeon-dong, Suji-gu, Gyeonggi-do 448-701, Korea \\ *Applied Rheology Center, Department of Chemical and Biomolecular Engineering, Sogang University, Seoul 121-742, Korea
}

(Received October 21, 2013; Revised December 11, 2013; Accepted December 13, 2013)

\begin{abstract}
초록: 고온용 초음파 측정 시스템을 장착한 이축압출기를 이용하여 고에너지 물질 시뮬란트의 분산도를 실시간으로 모니터링하는 연구를 하였다. 결합제 수지 및 충전제로 ethylene vinyl acetate(EVA)와 Dechlorane plus 25를 각각 사용하여 고에너지 물질 시뮬란트 현탁계를 구성하였다. 충전 부피분율이 증가함에 따라 현탁계의 초음파 속도는 전혀 변화를 보이지 않았으나 초음파 감쇠는 선형적으로 감소하였는 바 고르게 분산된 현탁계를 대상으로 초음파 감쇠를 측정하면 충전함량을 추정할 수 있음을 확인하였다. 또한 $60 \mathrm{v} \%$ 이상으로 충전된 고농축 현탁계에서는 반복 압출실험을 수행한 결과 초음파 감쇠의 편차가 감소하여 직선값에 접근하는 경향을 보이는 바 분산도의 증가하는 것을 알 수 있었다. 따라서 on-line 및 in-line으로 측정된 초음파 감쇠와 off-line으로 SEM 및 Image Analyzer 그리 고 열중량분석을 병행함으로써 분산도 및 충전 함량을 평가할 수 있을 것으로 사료된다.
\end{abstract}

\begin{abstract}
We studied in-line monitoring the dispersion of highly energetic material simulant by a twin screw extruder having a high temperature ultrasonic system. The simulant suspension system consisted of ethylene vinyl acetate and Dechlorane plus 25 as binder and filler, respectively. With increasing filling fraction, the ultrasonic velocity was not changed but the attenuation linearly decreased. It was possible to estimate the solid fraction of well dispersed suspension system by measuring ultrasonic attenuation. The ultrasonic attenuation of samples filled over $60 \mathrm{v} \%$ approached straight line with increasing filling fraction when the samples was extruded repeatedly. It was due to the enhanced dispersion of solid particles in the suspension system. It was believed that the degree of dispersion and filling fraction could be obtained by combination of on-line measurement like ultrasonic attenuation and off-line analysis like TGA and SEM with image analyzer.
\end{abstract}

Keywords: simulant, energetic, concentrated, in-line monitoring, dispersion.

\begin{abstract}
서
론

충전 고분자계에서는 충전 입자의 분산도가 기계적 물성에 직접적인 영향을 미치는 매우 중요한 인자이므로, 분산도를 높이기 위한 다양한 성형법의 개발과 함께 입자의 분산도를 정확하게 측정할 수 있는 측정법들이 개발되고 있다. 분산도 는 일반적으로 복합체 내에 충전된 총 입자의 함량에 대한 분배 혼합에 의한 결과로서 비응집 입자의 형태로 존재하게 되는 입자의 함량 비나 분산 혼합 시 임계 크기 이하로 존재 하는 작은 크기의 입자의 함량 비를 의미하며, 이를 측정하
\end{abstract}

${ }^{\dagger}$ To whom correspondence should be addressed.

E-mail: jwlee@sogang.ac.kr
기 위한 기술로는 광학 현미경이나 주사 전자현미경을 이용 하여 광학적으로 관찰하는 방법, 표면 조도를 측정하거나, ${ }^{1}$ 전 기전도도와 유전율 측정하는 방법들이 ${ }^{2}$ 주로 이용되고 있으 며 최근에는 핵자기 공명법과 ${ }^{3} \mathrm{X}$-선 산란법 ${ }^{4}$ 등도 이용되고 있다.

이들 중에서 시편을 박편 절단기로 잘라낸 다음 표면을 주 사 전자현미경으로 관찰하고 image analyzer를 이용하여 표 면을 기준으로 한 수평균 분산지수와 ${ }^{5,6}$ 부피평균 분산지수를 7 구하는 광학적 방법이 가장 널리 이용되고 있으나, 측정시간 이 길고 생산되는 제품의 품질을 실시간으로 제어할 수 없다 는 단점이 있으며, 핵자기 공명법과 X-선 산란법 등은 고농 축 현탁계에 대해서는 적용이 용이하지 않은 단점이 있다.

특히 이축 압출기를 이용하여 고농도 충전된 입자들이 고 
르게 분산된 고점도 에너지물질을 연속으로 성형 - 생산하기 위한 본 연구의 목적을 달성하기 위해서는, on-line 상에서 분 산도를 측정함으로써 품질의 균질성을 제어할 수 있는 방법 의 개발이 필수적으로 요구되고 있다.

초음파 모니터링 방법이 고체 상태와 용융 상태에서 고분 자의 특성을 측정하는데 많이 사용되어 왔으며, ${ }^{8-10}$ 다양한 산 업에서의 응용을 목표로 한 최근의 연구결과들은 초음파 속 도와 감쇄의 실시간 측정이 공정 모니터링의 강력한 툴이 될 수 있음을 보여 주고 있다. ${ }^{11-14}$ 특히 입자가 충전된 폴리올레 핀 용융체를 대상으로 수행한 실험에서 다성분계에서 초음파 속도와 감쇄가 충전제의 농도, 입자 크기 등과 상관관계가 있 다는 사실이 보고되었다. ${ }^{15-17}$

Brown 등은 ${ }^{12}$ 고속 샘플링 테이터 획득 보드와 고온용 초 음파 탐지기를 사용하여 고온으로 유지되고 있는 용융 복합 체를 대상으로 비파괴 초음파 측정을 시도하였고, 운전을 정 지한 상태인 압출, 사출공정에서 $10 \mathrm{~Hz}$ 이하의 샘플링 속도 를 사용하여 초음파 통과 시간을 측정한 결과, 통과 시간과 용융 온도, 압력간의 강한 상호작용은 용융 공정과 물질 변 수에 따라 매우 민감한 나타나는 것을 규명하였다.

Tatibouët와 Huneault는 ${ }^{18} \mathrm{PP}$ 수지에 탄산칼슘이 충전된 복 합계를 대상으로 고주파수의 초음파 측정장치를 사용하여 초 음파 속도와 감쇄 현상을 조사하여 탄산칼슘의 분산도를 실 시간으로 측정할 수 있는 기술을 개발하였는데, 탄산칼슘의 충전 함량이 $60 \mathrm{wt} \%(32.8-34.8 \mathrm{v} \%)$ 까지의 고농도로 충전된 계에 대해서도 실험을 수행한 결과 실시간으로 측정된 초음 파 측정 결과가 광학적 방법으로 측정된 분산지수와 매우 큰 상관관계가 있음을 보고하였다.

Haïder와 Tatibouët은 ${ }^{19}$ 다분산 필러들의 고분자 용융체에서 의 전단 분산 공정의 실시간 초음파 측정을 수행하고 다분산 프랙탈 클러스터의 전단 파쇄 과정을 초음파 산란 기법을 써 서 조사하였다. 압출 공정에서 PP 수지와 컴파운딩되는 실리 카 입자들의 전단 파쇄 과정을 실시간 측정하고 임계 비응집 전단응력을 구하였으며, 충전 입자의 표면처리 농도가 증가 하면 임계 비응집 전단응력이 감소함을 규명하였다.

G. D. Smith 등은 ${ }^{20}$ 비파괴 초음파 기술을 사용하여 $\mathrm{HDPE}$ 용융수지에 충전된 탄소 입자의 분산도의 차이를 결정하고자 하였는데, HDPE 수지 자체 뿐만아니라 세 종류의 서로 다른 분산도(고, 중, 저분산)를 갖는 복합계를 대상으로 초음파 속 도에 대응하는 초음파 전달 시간을 측정하여 비교하였다. 실
험은 운전을 정지한 오프라인 상태와 압출을 수행하면서 측 정하는 인라인 상태의 두 경우 모두에 대해 행해졌으며, 오 프라인 상태에서는 고, 중분산 복합체에 비하여 저분산된 복 합체의 초음파 전달 시간이 급격하게 증가하는 것이 관찰되 었으나 압출을 수행하는 인라인 상태에서는 이런 차이점을 관찰할 수 없었다.

Sun 등은 ${ }^{21}$ 충전 입자의 종류 및 농도 등의 입자 충전 조건 과 공급 속도, 스크류 회전 속도 및 배럴 온도 등의 운전 조 건을 다양하게 변화시키면서 실험을 수행하였는데, 압출기 모 터 드라이브의 암페어미터뿐만 아니라 초음파 센서, 온도 및 압력 센서들을 사용하여 입자가 충전된 고분자 복합계의 압 출 거동을 조사하였다. 또 충전입자의 분산 지수와 세 종류 의 변수, 즉 스크류의 회전속도, 입자 주입속도 등과 같은 압 출 제어 변수, 압출 과정 중에 측정되는 온도, 압력 등과 같 은 압출에 의존하는 측정 변수, 초음파 측정에 기초하는 압 출기와 무관한 측정 변수간에 인공지능 신경망을 구축하고 학습시킨 다음, 혼련 과정 중에 얻게 되는 초음파 측정 데이 터를 인공지능 신경망의 입력으로 사용함으로써 충전된 입자 의 분산도를 정확하게 예측할 수 있는 방법을 제시하였다.

Smith 등은 ${ }^{22}$ magnesium hydroxide로 충전된 LDPE를 압 출할 때 초음파를 사용하여 충전 입자 농도를 측정하고자 하 였다. 운전 중이 아닌 정지된 시료를 사용하여 온도, 압력, 충 전 입자의 농도가 초음파 속도에 미치는 상대적 효과를 일정 온도 압력 범위에서 조사하였는데, 초음파 속도는 온도의 변 화에 가장 민감하게 변하며 압력 변화에 대해 가장 덜 민감 하게 나타남을 볼 수 있었으며, 복합계와 순수 수지를 대상 으로 하여 얻은 초음파 측정 결과로부터 $\mathrm{LDPE}$ 수지에 충전 된 magnesium hydroxide의 중량 $\%$ 를 결정하였다. 압출시 얻 은 초음파 데이터로부터 계산된 중량 $\%$ 값과 열중량 분석에 의해 구한 중량 $\%$ 값을 압출 시간에 따라 비교한 결과 절대 값에서는 약간의 차이를 보이지만 충전 함량이 변하는 거동 은 비슷한 경향을 보임을 알 수 있었다.

\section{실 험}

원료. 결합제 수지로 탄성 특성이 우수한 ethylene vinyl acetate(EVA)를 사용하였으며, vinyl acetate 함량이 30\%인 EVA31을 사용하여 혼련 특성을 조사하였다. 실험에 사용한 결합제 및 충전제의 물성을 Table I에 수록하였고 충전제인

Table 1. Properties of Materials Used in This Study

\begin{tabular}{lcccc}
\hline \multicolumn{1}{c}{ Trade name } & Material & Density $\left(\mathrm{g} / \mathrm{cm}^{3}\right)$ & $T_{\mathrm{m}}\left({ }^{\circ} \mathrm{C}\right)$ & Remark \\
\hline EVA31 & $\begin{array}{c}\text { Ethylene vinyl acetate copolymer } \\
\text { (USI Chem) }\end{array}$ & 0.95 & 52 & Melt index*:18 \\
\hline Dechlorane 25 & $\mathrm{C}_{18} \mathrm{H}_{12} \mathrm{Cl}_{12}($ Oxychem) & 1.8 & $350 \mathrm{w} /$ decomp & Mean particle size: $4.5 \mu \mathrm{m}$ \\
\hline *ASTM 1238. & & &
\end{tabular}


<smiles>ClC1=C(Cl)C2(Cl)C3CCC4C(Cl)(Cl)C(Cl)=C(Cl)C4(Cl)C(Cl)C3CCC2C(Cl)C1(Cl)Cl</smiles>

Scheme 1. Structure of Dechlorane 25.

Dechlorane 25의 구조를 Scheme 1에 도시하였다.

초음파 In-Line 모니터링 시스템. 본 연구에서는 $10 \mathrm{MHz}$ 의 주파수를 발생시키는 초음파 단자를 사용하여 Figure 1과 같이 한쪽 초음파단자에서 발산된 신호를 맞은편 초음파단 자에서 받는 형태의 투과전송방식(through transmission mode) 을 사용하였다. 초음파 속도 $\left(V_{\mathrm{US}}\right)$ 는 Figure 1에서의 신호전달 그래프에서 연속적인 에코(echo) 사이의 시간차 $\Delta t$ 로부터 다 음과 같이 구한다.

$$
V_{\mathrm{US}}=\frac{2 e}{\Delta t}
$$

여기서, $e$ 는 버퍼로드 사이의 시료가 존재하는 영역의 간격 을 의미한다. 초음파 감쇠(attenuation)는 Figure 1에서 연속 적인 에코 크기의 비율로부터 다음과 같이 구한다.

$$
\alpha=\frac{10 \log \left(A_{1} / A_{2}\right)}{e}
$$

실제 초음파 측정 신호의 예를 Figure 2에 나타내었다. 초
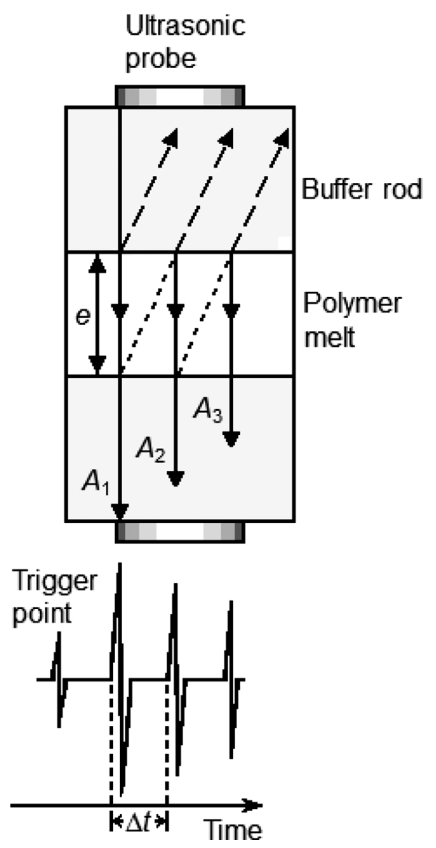

Figure 1. Schematics of ultrasonic measurement: (a) system and mechanism of ultrasonic; (b) output of ultrasonic signal.

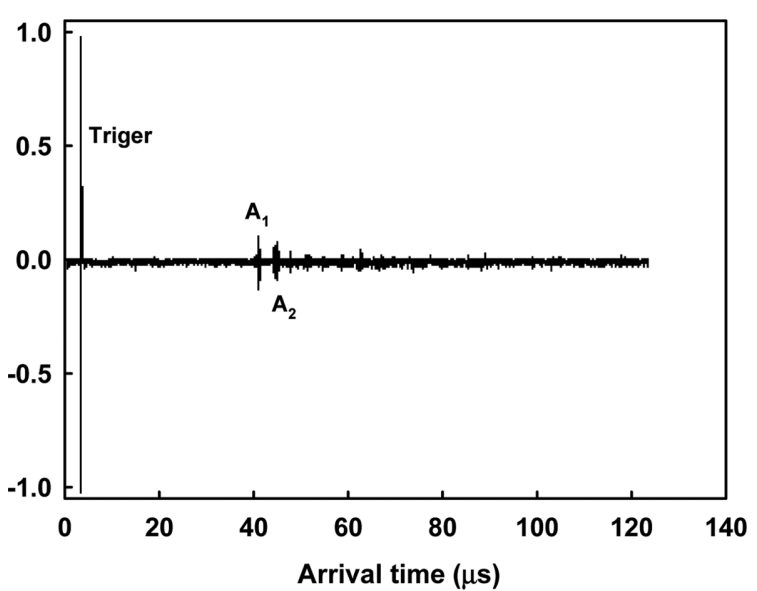

Figure 2. Actual ultrasonic signal.

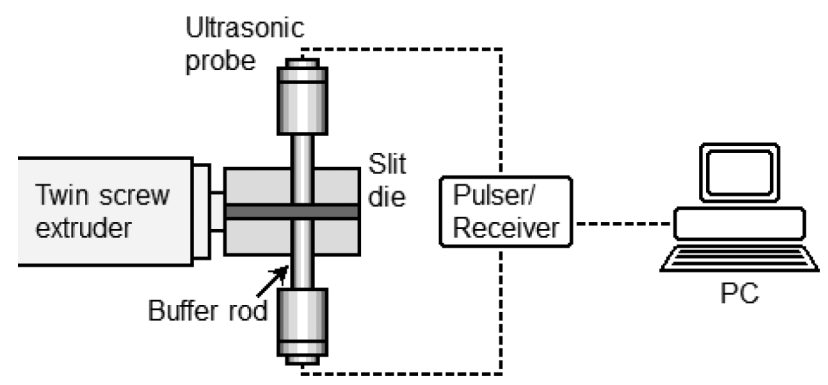

Figure 3. In-line ultrasonic monitoring system.

음파 신호는 pulser/receiver(5072PR, Panametrics) 장치에서 제어되고, 이때 얻어진 신호들은 Figure 3에서와 같이 고속 데이터 획득 보드(data acquisition board)를 통해 컴퓨터에 저 장된다. Piezoelectric device로 구성되어 있는 초음파 단자 (ultrasonic probe)는 사용온도의 최대 범위가 $50{ }^{\circ} \mathrm{C}$ 부근으로 대부분의 고분자 가공온도에서 견디지 못하기 때문에, 스텐 레스 스틸 버퍼로드(buffer rod)를 제작하여 그 위에 초음파 단자를 부착하였고, 초음파 단자로의 열전달을 억제하기 위 해 에어냉각장치를 장착하였다. 서로 마주보는 두 개의 초음 파 센서, 세 개의 압력 센서를 부착할 수 있는 슬릿 다이를 제작하였다. 위의 슬릿 다이를 Haake 이축압출기(Rheomex CTW100/Conical Twin Screw Extruder)에 부착하였다. Haake 이축압출기는 intermeshing counter-rotating type이며, 스크루 직경은 $31.8 / 20 \mathrm{~mm}$ (rear/front)이고 스크루 길이는 $300 \mathrm{~mm}$ 이 다. Haake 이축압출기 배럴은 공급구(feed opening) 이 후 세 개의 영역(zone)으로 나누어져 있고 각 영역은 독립적으로 온 도 조절이 가능하나 본 실험에서는 세 개의 영역과 다이의 온도들을 모두 같게 설정하였다.

\section{결과 및 토론}

먼저 순수 EVA31 용융체에 대하여 온도 및 가공속도의 변 


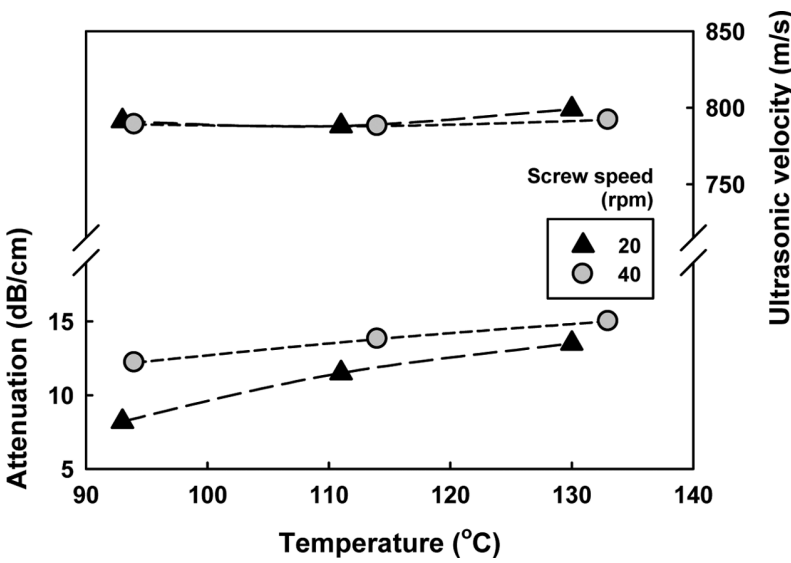

Figure 4. Ultrasonic velocity and attenuation vs. temperature for neat EVA31 melt.

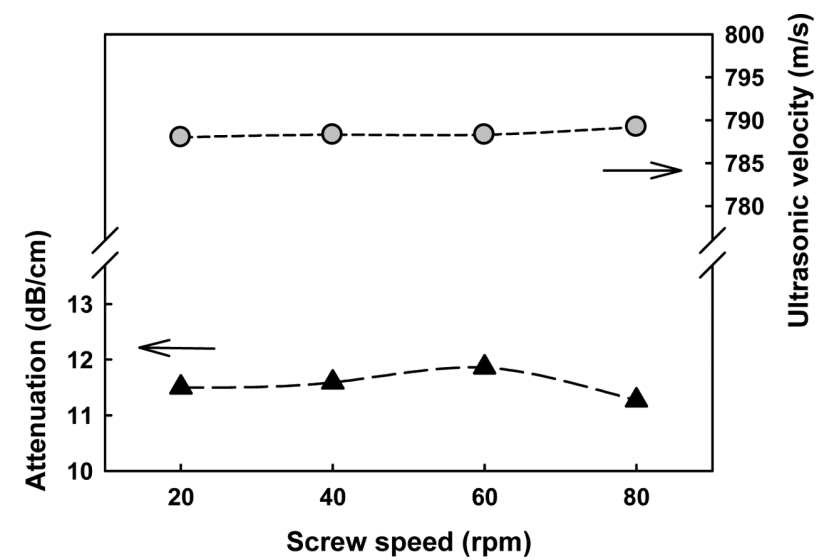

Figure 5. Ultrasonic velocity and attenuation $v s$. screw speed for neat EVA31 melt at $120^{\circ} \mathrm{C}$.

화에 따른 초음파 속도와 감쇠의 변화를 조사하였다. Figure 4에서 보는 바와 같이 초음파 속도는 온도에 따라 상대적으 로 큰 변화가 없었으나 감쇠는 온도가 증가할수록 거의 선형 적으로 증가하는 것을 볼 수 있었다. 또한 압출기 스크류 속 도에 대한 영향을 보다 자세히 관찰하기 위해 용융체 온도가 $120^{\circ} \mathrm{C}$ 가 되도록 조절하면서 스크류 속도를 변화시켜 보았는 데 Figure 5에 보이는 바와 같이 초음파 속도는 스크류 속도 에 대해서는 큰 변화는 없는 것으로 관찰되었고 감쇠 또한 경향으로 보기에는 어려울 정도의 변화만 보였다.

EVA31/Dechlorane(80/20) 현탁계를 대상으로 순수 EVA31 에 대해서와 마찬가지로 온도 및 가공속도의 변화에 따른 초 음파 속도와 감쇠의 변화를 조사하였다. 온도에 대한 거동을 Figure 6에 도시하였는데, 초음파 속도는 거의 변화를 발견할 수 없었으나 감쇠는 온도가 증가함에 따라 $1.5 \mathrm{~dB} / \mathrm{cm}$ 정도 증가하였다가 $120^{\circ} \mathrm{C}$ 이후에는 다시 감소하는 경향을 보였 다. 스크류 속도에 따른 효과 또한 Figure 7에서 보는 바와 같이 변화를 보였는데 스크류 속도가 증가함에 따라 초음파

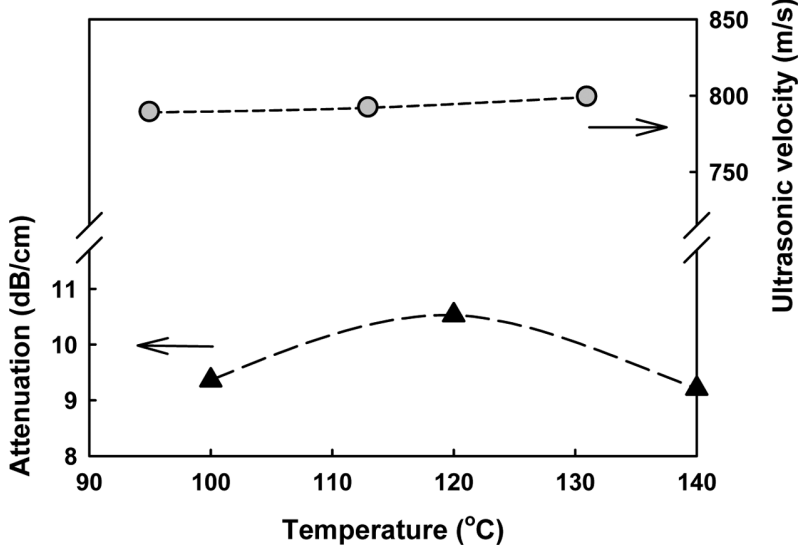

Figure 6. Utrasonic velocity and attenuation vs. temperature for EVA31/Dechlorane (80/20) suspension at $40 \mathrm{rpm}$.

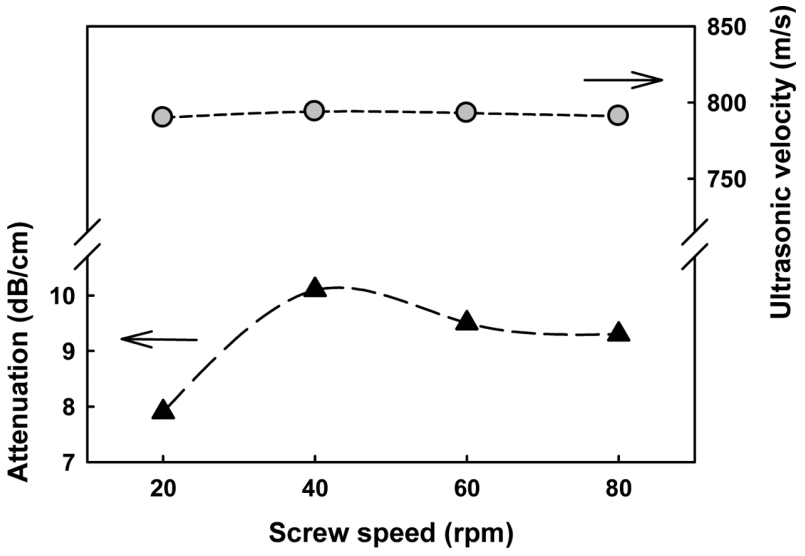

Figure 7. Ultrasonic velocity and attenuation vs. screw speed for EVA31/Dechlorane (80/20) suspension.

속도는 변화를 보이지 않은 반면에 감쇠는 $40 \mathrm{rpm}$ 일 때까지 약 $2 \mathrm{~dB} / \mathrm{cm}$ 정도 증가하였다가 그 이상에서는 다시 감소하 다가 거의 일정한 값을 유지하였다. 초음파 속도에는 큰 변 화가 없었으며 감쇠는 스크류 속도 20에서 $40 \mathrm{rpm}$ 까지는 증 가하다가 그 이상의 스크루 속도에서는 약간 감소하기는 하 지만 거의 일정한 값을 유지하였다. 이상과 같은 결과로부터 현탁계를 투과하는 초음파 거동은 온도 및 스크류 회전 속도 같은 운전조건의 변화에 영향을 받으며 내부의 분산도 등의 변화는 초음파 속도보다는 감쇠 효과에 더 민감하게 나타나 는 바 감쇠 거동과 분산도 등과의 연관성을 규명하여 in-line monitoring에 활용이 가능하다고 사료된다.

Figure 8에 EVA31/Dechlorane 현탁계의 충전제 농도에 따 른 초음파 속도 및 감쇠의 변화를 나타내었는데 충전제 농도 가 증가함에 따라 초음파 속도는 큰 변화가 없는 반면에 감 쇠는 충전제 농도 $40 \mathrm{v} \%$ 까지는 감소하다가 그 이상에서는 약 간 증가하였다. 고충전 현탁계의 초음파를 이용한 농도 측정 에 관한 많은 연구들이 있었지만, 대부분의 연구는 충전제 농 


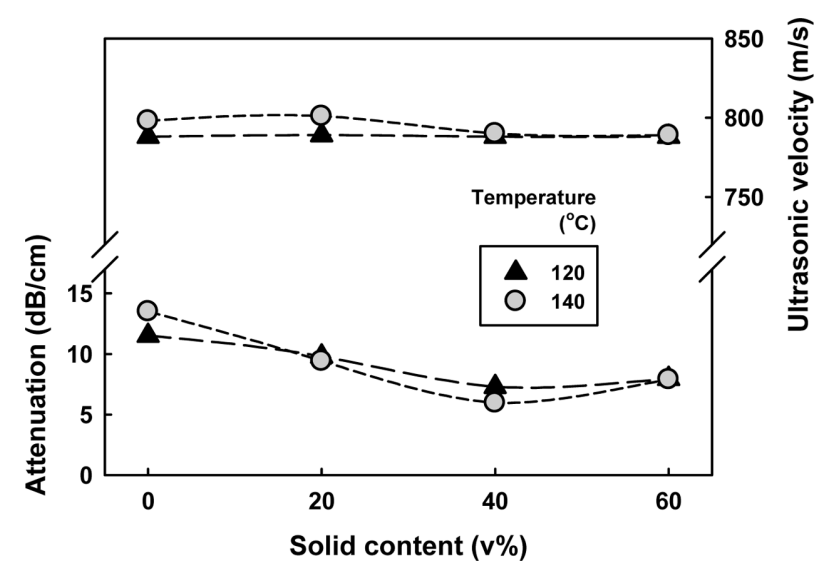

Figure 8. Ultrasonic velocity and attenuation $v s$. solid content for EVA31/Dechlorane suspensions at $40 \mathrm{rpm}$.

도 $60 \mathrm{v} \%$ 이하에서 행해졌다. Smith 등은 ${ }^{23} \mathrm{LDPE} / \mathrm{magnesium}$ hydroxide 시스템에서 초음파 속도는 28-32 wt\%의 magnesium hydroxide 농도 범위에서 초음파 속도는 충전제 농도와 선형 관계이지만 33-50 wt\%의 범위에서는 초음파 속도와 농도가 선형 관계가 아님을 언급하였다. 또한 농도가 증가할수록 감 쇠가 증가할 것으로 예상하였으나 $10 \mathrm{wt} \%$ 에서만 이러한 경 향이 감지되었고 그 이상의 농도에서는 감쇠 신호가 너무 커 서 두 번째 피크를 배경 노이즈로부터 구분하기가 힘들었다 고 보고하였다. 본 연구의 경우 Smith 등의 결과와 달리 EVA/ Dechlorane 현탁계는 0-40 v\% 범위에서 감쇠-충전분율의 직 선 상관관계를 보였다. 충전제 농도 $60 \mathrm{v} \%$ 에서 감쇠가 다시 약간 증가하는 것은 고농도에서 입자-입자간의 상호작용의 증가와 관련있다고 사료된다.

충전농도가 $60 \mathrm{v} \%$ 인 경우와 그 외의 농도인 경우의 감쇠 거동의 차이를 좀 더 명확히 보기 위하여 Figure 9에 각 농 도에서의 현탁계들의 감쇠를 시간의 함수로 나타내었다. 감

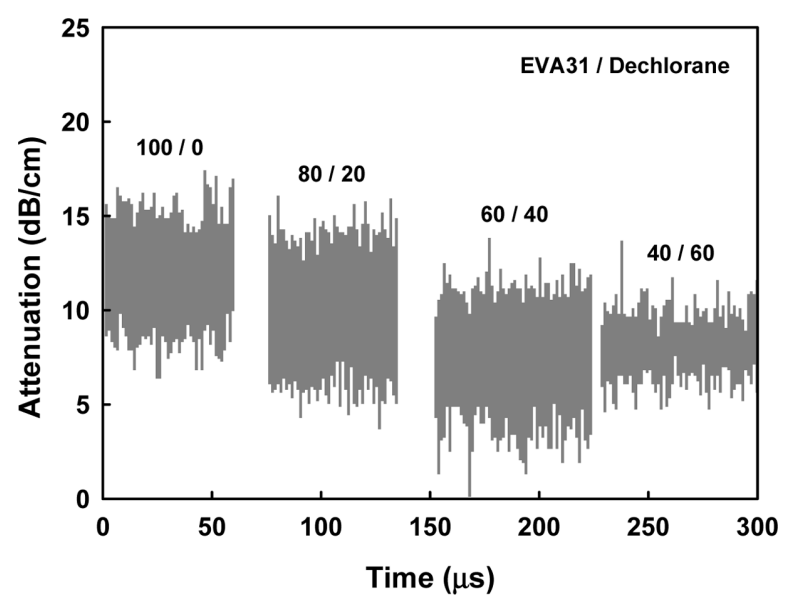

Figure 9. Attenuation of EVA31/Dechlorane suspensions at $120^{\circ} \mathrm{C}$.
쇠는 충전제 함량뿐만 아니라 입자나 응집체의 크기에 민감 하므로 감쇠의 노이즈는 물질의 균일성을 나타낸다고 할 수 있는데 EVA31/Dechlorane(40/60) 현탁계의 경우 더 좁은 노 이즈 편차를 보이는 것으로 보아 충전제가 보다 균일한 분포 를 갖는 것으로 판단된다.

Figure 10 에는 감쇠 데이터에 대하여 시간 진동수 분석을 시도하였는데 감쇠 구간 $\alpha+\Delta \alpha$ 의 범위에서의 데이터의 수 (number of events)를 감쇠 $\alpha$ 에 대해 도시하였다. 여기서 $\Delta \alpha$ 는 $0.01 \mathrm{~dB} / \mathrm{cm}$ 로 하였다. 충전제 함량이 증가함에 따라 감쇠 의 전반적인 감소를 관찰할 수 있었으나 농도가 $60 \mathrm{v} \%$ 인 현 탁계는 이러한 경향에서 벗어날 뿐 아니라 데이터의 수 피크 값 또한 작은 등 다른 농도의 현탁계들에 비해 다른 거동을 보이는 것을 알 수 있다.

Figure 8 10에서 관찰된 충전농도 $60 \mathrm{v} \%$ 에서의 감쇠의 증 가를 규명하고자 $120^{\circ} \mathrm{C}$ 에서 EVA31/Dechlorane(40/60) 현탁

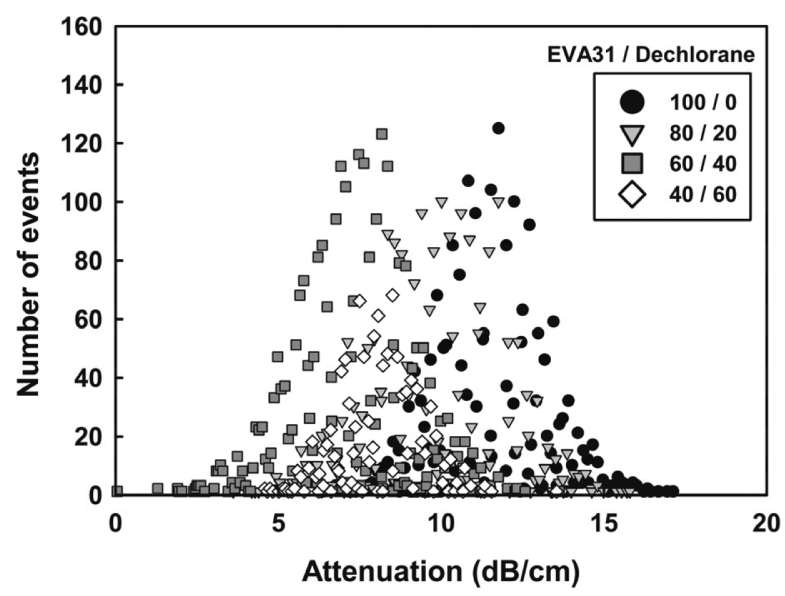

Figure 10. Frequency analysis of attenuation data for EVA31/ Dechlorane suspensions at $120^{\circ} \mathrm{C}$.

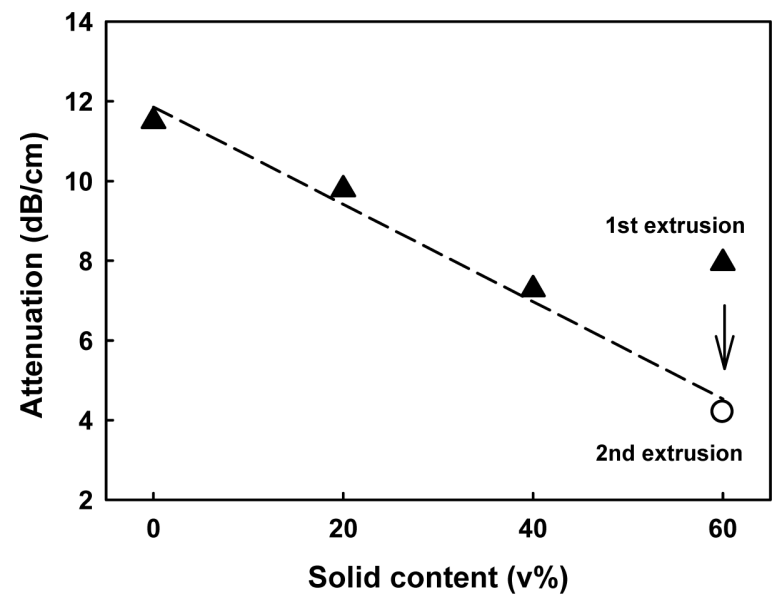

Figure 11. Ultrasonic attenuation vs. solid content for EVA31/ Dechlorane suspensions. 
계에 대하여 압출되어 나온 시료를 잘라서 다시 압출기에 주 입하는 반복 압출 실험을 수행하였다. Figure 11은 Figure 8 의 $120^{\circ} \mathrm{C}$ 에서 충전제 함량에 따른 감쇠 결과를 확대한 것으 로 동일한 검은 삼각형으로 표시하였다. $120^{\circ} \mathrm{C}$ 에서의 $\mathrm{EVA} 31 /$ Dechlorane $(40 / 60)$ 현탁계의 초음파 감쇠값은 반복 압출 실험 을 수행할수록 현저하게 떨어지는 것을 발견하였으며, 3회 정 도 반복 압출 실험을 수행하였을 때의 초음파 감쇠 결과는 그림에서 흰 원으로 표시한 바와 같이 충전율에 대해 초음파 감쇠가 선형적으로 감소하는 직선 상의 값을 갖는 것을 볼 수 있다. 따라서 이상의 사실로 미루어 고충전 함량 조건에 서 편차를 보이는 초음파 감쇠 효과는 혼화도 차이에 기인하 는 것으로 판단되며 현탁계 제조시 이러한 초음파 감쇠를 이 용하여 in-line으로 분산정도를 모니터링하는 것이 가능하리 라고 사료된다.

\section{결 론}

이축 압출기를 이용하여 고농축 현탁계를 혼련할 때 충전 함량과 분산도를 모니터링하기 위한 고온용 초음파 측정 시 스템을 개발하였다. 고온용 초음파 측정시스템은 pulser/ receiver와 $10 \mathrm{MHz}$ 의 초음파 단자, 버퍼로드 및 고속 데이터 획득 보드로 구성하였다. 현탁계의 초음파 속도는 충전 부피 분율에 따라 전혀 변화를 보이지 않았으나 초음파 감쇠는 충 전 부피분율이 증가함에 따라 선형적으로 감소하는 경향을 보임을 알 수 있었으며, 이로부터 고르게 분산된 현탁계를 대 상으로 초음파 감쇠를 측정하면 충전함량을 추정할 수 있음 을 확인할 수 있었다. 또 $60 \mathrm{v} \%$ 이상이 충전된 고농축 현탁 계에서는 초음파 감쇠가 직선값으로부터 편차를 보이는데, 이 는 반복 압출 실험을 수행한 결과 초음파 감쇠가 감소하여 직선값에 접근하는 경향을 보이는 것으로 미루어 볼 때 현탁 계의 분산성과 관련이 있음을 알 수 있었다. 따라서 on-line 및 in-line으로 측정된 초음파 감쇠와 SEM 및 image analyzer 를 이용하여 오프라인으로 측정한 분산도 및 열중량분석을 통한 충전 함량 결과를 연결하면 초음파를 이용하여 분산도 및 충전 함량을 측정할 수 있을 것으로 판단된다. 그러나 다 양한 충전조건(결합제 종류 및 특성, 충전제의 종류 및 특성, 입자의 크기 및 입도분포, 충전함량 및 함량비 등)과 운전조 건(온도, 회전속도, 압출기 내의 스크루 배열 등)의 변화에 따 른 오프라인 결과를 모두 측정하여 초음파 감쇠 결과와 연관 을 짖는 것은 불가능하기 때문에 일부 선정된 조건에서의 online으로 측정된 초음파 감쇠 결과와 오프라인 측정결과를 인 공지능 신경망을 통하여 학습시킨 다음 다른 조건에서 수행
된 실험에서 얻은 초음파 결과로부터 분산도 및 충전함량을 예측하는 연구가 향후 필요하다고 생각된다.

감사의 글: 본 연구는 (주)한화와 국방과학연구소의 지원으 로 수행되었으며, 이에 감사드립니다(계약번호: UC120019GD)

\section{참 고 문 헌}

1. B. M. Mutagahywa and D. A. Hemsley, Plast. Rubber Proc. Appl., 5, 219 (1985).

2. M. Pello, Plast. Rubber Compos., 29, 207 (2000).

3. P. P. Sukhanov, A. E. Zaikin, and V. S. Minkin, Int. Polym. Sci. Tech., 16, T15 (1989).

4. S. Okuda and K. Fujisawa, Proceedings Mechanical Behavior of Materials Conference VI, Pergamon Press, Kyoto, Japan 1991, 671 (1992).

5. Y. Suetsugu, Int. Polym. Process., 3, 184 (1990).

6. R. Gendron and D. Binet, J. Vinyl Addit. Techn., 1, 54 (1998).

7. J. W. Ess and P. R. Hornsby, Plast. Rubber Proc. Appl., 8, 147 (1987).

8. A. Sahnoune and L. Pich, J. Non-cryst. Solids, 235, 664 (1998).

9. A. Sahnoune, F. Massines, and L. Pich, J. Polym. Sci., 2, 341 (1996).

10. C. Verdier, P.-Y. Longin, and M. Piau, Rheol. Acta, 37, 234 (1998).

11. H. Wang, C.-K. Jen, K. T. Nguyen, and M. Viens, Polym. Eng. Sci., 2, 363 (1997).

12. E. C. Brown, T. L. D. Collins, A. J. Dawson, P. Olley, and P. D. Coates, SPE ANTEC, 44, 335 (1998).

13. J. Shen, R. Edwards, C. L. Thomas, and A. T. Bur, SPE ANTEC, 44, 2076 (1998).

14. L. Piche, SPE ANTEC, 44, 3617 (1998).

15. L. Erwin and J. Dohner, Polym. Eng. Sci., 16, 1277 (1984).

16. B. Bridge and K. H. Cheng, J. Mater. Sci. Lett., 6, 219 (1987).

17. R. Gendron, M. M. Dumoulin, J. Tatibouet, and L. Piche, SPE ANTEC, 39, 2256 (1993).

18. J. Tatibout and M. A. Huneault, Int. Polym. Proc. XVII, 1, 49 (2002).

19. L. Hader, J. Tatibout, A. Lafaurie, and L. Ferry, J. Phys. Condens. Mat., 14, 4943 (2002).

20. G. D. Smith, E. C. Brown, D. Barnwell, K. Martin, and P. D. Coates, Plast. Rubber Compos., 32, 167 (2003).

21. Z. Sun, C.-K. Jen, J. Yan, and M.-Y. Chen, Polym. Eng. Sci., 45, 764 (2005).

22. G. D. Smith, E. C. Brown, D. Barnwell, K. Martin, and P. D. Coates, Plast. Rubber Compos., 32, 248 (2003).

23. G. D. Smith, E. C. Brown, and P. D. Coates, SPE Tech Papers, XLVII, 3105 (2001). 